\title{
Correction to: The use of lecture capture in university mathematics education: a systematic review of the research literature
}

\section{Euan Lindsay ${ }^{1} \cdot$ Tanya Evans $^{1}$}

Published online: 11 June 2021

(C) Mathematics Education Research Group of Australasia, Inc. 2021

\section{Correction to: Mathematics Education Research Journal https://doi.org/10.1007/s13394-021-00369-8}

The original version of this article unfortunately contained an incorrect text. Monash University and the University of Melbourne should be "two Australian universities."

Publisher's Note Springer Nature remains neutral with regard to jurisdictional claims in published maps and institutional affiliations.

The original article can be found online at https://doi.org/10.1007/s13394-021-00369-8.

Tanya Evans

t.evans@auckland.ac.nz

1 Department of Mathematics, University of Auckland, Auckland, New Zealand 